\title{
Feasibility study of a grid-tied 2MW floating solar PV power station and e-transportation facility using 'SketchUp Pro' for the proposed smart city of Pondicherry in India
}

\author{
Ankit Kumar Singh ${ }^{1}$, Dwipen Boruah ${ }^{2}$, Lakshey Sehgal ${ }^{3}$ and Ramaswamy Arun Prasath ${ }^{*}$ \\ ${ }^{1}$ Laboratory for Energy Materials and Sustainability, Centre for Green Energy Technology, Pondicherry University, \\ Puducherry 605014, India \\ ${ }^{2}$ GSES India Sustainable Energy Pvt. Ltd., New Delhi 110019, India \\ ${ }^{3}$ BA-PAN Engineering Co., New Delhi 110020, India
}

\begin{abstract}
The race of smart cities in India places Pondicherry at $75^{\text {th }}$ position. To improve its ranking position for smart city race, we propose the implementation of 2MW Floating Solar Photovoltaic (FSPV) system where a large water body could be used for generation of solar power. The floating PV system can be used to attain much higher efficiency compared to its counterpart on land based PV system. The proposed FSPV system could cover solar panel of $1 / 3^{\text {rd }}$ area of the proposed lake to generate $2685 \mathrm{MWh}$ annually. A geo-synchronized layout has been prepared using 3D SketchUp Pro with Google maps. The FSPV system could cost USD 1.6 million with a payback period of 6 years. In addition, the implementation of e-transport facility by utilizing e-rickshaws with a battery capacity of 90Ah with 15 Amps DC charging facility has been proposed with an investment of USD 30000, with payback period of just 5 months. The bright side being improved overall payback due to money inflow with the implementation of e-rickshaws; greater job opportunities with benefits to physically challenged persons to improve their overall socio economic status. It is viewed that the proposed FSPV and e-transport could increase the chance to secure smart city plan for Pondicherry.
\end{abstract}

Keywords: smart city, power plant, floating solar photovoltaic, grid-tied, e-transportation facility, e-rickshaws

*Correspondence to: Ramaswamy Arun Prasath, Laboratory for Energy Materials and Sustainability, Centre for Green Energy Technology, Pondicherry University, Puducherry 605014, India; Email: raprasath.get@pondiuni.edu.in

Received: September 27, 2016; Accepted: November 17, 2016; Published Online: December 30, 2016

Citation: Singh A K, Boruah D, Sehgal L, et al., 2016, Feasibility study of a grid-tied 2MW floating solar PV power station and e-transportation facility using 'SketchUp Pro' for the proposed smart city of Pondicherry in India. Journal of Smart Cities, vol.2(2): 49-59. http://dx.doi.org/10.26789/JSC.2016.02.004.

\section{Introduction}

\subsection{General Overview}

$\mathrm{T}$ The $21^{\text {st }}$ century is regarded as the century of cities. According to the recent report by UN Department of Economic and Social Affair, more people live in urban areas than in the rural areas.
This population shift has grown from 30 percent (746 million) in 1950 to 54 percent (3.9 billion) and is expected to be 66 percent by 2050 , adding around 2.5 billion to the present figures. For developing countries like India, the growth rate is more rapid compared to the American and European continent. India is expected to add 404 million urban dwellers to

Feasibility study of a grid-tied 2MW floating solar PV power station and e-transportation facility using 'SketchUp Pro' for the proposed smart city of Pondicherry in India. (C) 2016 Ankit Kumar Singh, et al. This is an Open Access article distributed under the terms of the Creative Commons Attribution-NonCommercial 4.0 International License (http://creativecommons.org/licenses/by- nc/4.0/), permitting all non-commercial use, distribution, and reproduction in any medium, provided the original work is properly cited. 
its cities in the next 30 years ${ }^{[1]}$. The unprecedented rate of urban growth has imposed risks and concerns such as: congestion, pollution, burdened resources, lack of energy, mismanagement. This has been seen very clearly in the case of the December 2015 flood in Chennai city and open areas. Thus, it came up as a motivation for a new idea of 'SMART CITIES'. The idea entails the concept of self-developing and people friendly environment using the advance technologies, management and feedback systems for a sustainable and energy independent city. The motivation to transform the present cities to more liveable ones, the government of India has taken an initiative of converting 100 cities into 'smart cities' to provide core infrastructure and sustainable environment that needs the application of sustainable management and promotion of territory with a bottom up approach to subside the crisis and concerns faced by the present cities. The Oulgaret municipality of Pondicherry is among one of those. A proposal for the smart city was put forward by the city and town planning department of Puducherry. The municipality has proposed the framework development approach of RRG (Retrofitting, Redevelopment, and Greenfield) that will be implemented under different strategies of development and integrated vision using innovative planning and smart solutions ${ }^{[2]}$.

One of the major key factors to make a city-smart is by tackling the energy demand through smart and innovative means. At present, the use of renewable energies is regarded as the perfect solution for growing energy demand as they are pollution free and economical. In the guidelines provided for the smart city development, one of the essential features mentioned is: assured electricity supply and $10 \%$ of the total consumption of the smart city to be produced from solar ${ }^{[3]}$. This feature is a step forward towards attaining energy independence and will be a guiding light for the upcoming cities in the race to become smart. Solar energy has gained an upper hand in the race of renewable technologies due to the long term research and development in this field. The technology today has become not just cheaper but also more effective and feasible in the equatorial countries where the solar irradiance is high. Government of India has aimed to achieve 100 GW through solar under JNNSM [Jawaharlal Nehru national solar mission] till $2022^{[4]}$. Under this mission government is planning to set up power plants throughout the country using solar thermal and solar photovoltaic technologies. The solar photovoltaic technology is comparatively more feasible and effec- tive in most of the areas it is easy to install in the remote locations and solar panels itself converts the sunlight directly to electricity (photovoltaic conversion). The major drawback with the solar technology is that it requires a large area, i.e., a $1 \mathrm{MW}$ power plant requires about 4-5 acres of land which cannot be further utilized for other purposes. Another such drawback is the increase in temperature of the solar cell. The paper focuses on proposing a floating solar photovoltaic system that can be installed on the water body present in the Karasur village.

\subsection{Why Floating Solar Photovoltaic (FSPV)?}

The FSPV system has the following advantages over the land based solar power plants. The land has become a shrinking commodity due to the rising population. This has exponentially increased the cost of the land thereby increasing the project cost; land utilized for the solar plants cannot be utilized for the other purpose, particularly in urban areas. These issues can be sorted out in FSPV system as it will utilize the water body. In addition, the land based systems are also prone to high temperature. The temperature has an indirect relation with the efficiency of solar power plants ${ }^{[5,6]}$. This means that the increase in the solar panel temperature decreases the power out efficiency in solar plant. Whereas in the floating system, the temperature around the panel reduces due to the evaporation and hence maintaining higher efficiency of generation than the land based system. The floating system also reduces the evaporation rate, maintaining the water level and also restricts the algal bloom by blocking out the sunlight ${ }^{[7]}$. The FSPV also embellishes the site making it a public attraction and can also be synced with a solar charging station at the site for the electric vehicles in the smart city area. This can be a very attractive means for the smart city as the proposal for solar PV over the canals helped the Coimbatore city to secure $13^{\text {th }}$ position in the race of smart city proposal in India. The Oulgaret municipality of Puducherry, which is ranked $75^{\text {th }}$, has been listed among the cities that have to upgrade in a special fast track initiative. There are 23 cities which have been included in this list and have been given a chance to upgrade their proposal to make it more attractive and smart. Among these 23 cities, the cities which achieve the benchmark set by the present top 20 cities will be funded on accelerated basis in 2016-2017 to achieve its goal of becoming a smart city ${ }^{[8]}$.

The rapid growth in transportation sector has con- 
tributes pollution in manifolds. The rise is due to the dependency of transportation sector over the nonrenewable resources. The present Indian government has come up with different schemes and benefits like "Deendayal E-Rickshaw Scheme" to promote the use of greener means of transportation and reduce the emission levels which renders us a smart solution to fight the serious issues like pollution and poverty trap ${ }^{[9]}$. A study shows that $80 \%$ of the e-rickshaw drivers have felt an increase in their daily wages and betterment in their living condition after shifting into the profession from their previous ones ${ }^{[10]}$. At present, India is highly dependent on non-renewable resources for its energy requirements. Thus, the charging facilities for electric vehicles would not entirely benefit until and unless they use renewable source to power the battery bank or for feeding the grid as otherwise it will only shift the site of pollution from the city to the outskirts, where these coal/diesel fired power plants are installed. Taking this into consideration, we included the charging facility in the vicinity that will be powered by the grid which is being fed by the floating solar PV system in the proposal. Hence, we propose a floating solar photovoltaic system along with a charging facility for the e-rickshaws for the location, helping the municipality to secure the position in the race of becoming a smart city.

\subsection{FSPV Systems across the Globe}

Choi has studied various factors such as wind, water flow, irradiation, shadowing, etc. to determine the suitability of the reservoir of Hapcheon Dam, South Korea for the floating system ${ }^{[11]}$. The comparison of power generation and environmental impact between the floating and land based PV system was discussed. The results showed that the power generation efficiency is higher in the floating system because of evaporation from water bodies and it also has a lesser environmental impact compared to land based system ${ }^{[12]}$. Lee et al. explored about the pultruded fibre reinforced polymeric plastic (FRP), which is a low-density, durable and recyclable material required to develop a light weight structure which can float over water and provides strength comparable to the conventional floating structure used for the PV system. Mechanical tests determine its appropriateness as a floating structure to support the PV system which was installed at a sea site in Korea ${ }^{[13]}$. The issues faced by land based solar PV systems and its elimination in the floating systems has been reported. It has been noted that the design parameters of a $10 \mathrm{~kW}$ floating solar PV system stating its cost to be 1.2 times more than the land based system ${ }^{[7]}$. Korean Water Resources Corporation (K-water) has completed the installation of two floating solar PV power plants at $100 \mathrm{~kW}$ and $500 \mathrm{~kW}$ respectively. Analysis and comparison of these two systems to their counterparts on land was done and found that the floating system had $10 \%$ greater generation efficiency than their counterparts on land ${ }^{[14]}$. The new Photovoltaic Floating Cover System (PFCS) for the agricultural reservoirs to minimize evaporation loss along with generating income in the form of electricity. This makes the system an efficient tool for agriculture industry ${ }^{[15]}$. The floating solar photovoltaic system proposed by Polienergie is suitable for any type of water surface. The system can accommodate any size of panel, highly adaptable to changes in water level and they used micro-inverter technology which eliminates the need of structures around water bodies for inverters. All the materials are recyclable and can also be installed over drinkable water reservoirs ${ }^{[16]}$.

A novel idea for the offshore PV system achieved by placing flexible thin film PV that floats on the surface. The cost and performance analysis was performed to compare to offshore wind installations. The results show that the PV system was economically competitive and the specific yield was higher for the thin film system than for other offshore technology when assessed in terms of $\mathrm{GWh} / \mathrm{km}^{2}{ }^{[17]}$. The Maltese island can exploit its solar potential through the offshore (floating) $\mathrm{PV}$ technology and integrate it to the conventional electric generation system to attain cost benefits and $\mathrm{CO}_{2}$ savings ${ }^{[18]}$. The offshore applicability of the solar technology also helps to exploit the opportunity to use it with other complimentary energy sources like wind and wave ${ }^{[19]}$. A water-saturated microencapsulated phase change material (MEPCM) has been studied in the water surface floating PV panels to show the effect on its temperature and power generation efficiency during summer. The results show that the power generation efficiency improved by $2.1 \%$ when the panels were treated with a $5 \mathrm{~cm} \mathrm{MEPCM}{ }^{[20]}$. The design feature, $\mathrm{CO}_{2}$ analysis, economic and other benefits of the FPCS (floating photovoltaic cover system) using a 20 kWp prototype was studied in detail by Redón et al. The results observed led to increase the installation by covering the entire area of the reservoir $\left(4490 \mathrm{~m}^{2}\right.$ and $300 \mathrm{kWp}$ ) generating 425,000 kWh/year, saving 5000 $\mathrm{m}^{3}$ of water annually and 2048.5 tonnes of $\mathrm{CO}_{2}$ for a service life of 20 years ${ }^{[21]}$. Meanwhile, the PV inte- 
grated floating surface that is technically feasible and economically viable was analysed ${ }^{[22]}$. A study for the use of floating PV in Brazil was conducted. A fraction of three selected reservoir was occupied by the system for the study and the results flashed an increase in average conversion efficiency of $12.5 \%$. PVSYST software was used to construct the electric production scenario which on comparison showed that energy produced by the PV system when spread over the entire area of the three reservoirs will be $18.8 \%$ of the electricity demand of its largest city Fortaleza ${ }^{[23]}$. A 100 kWp capacity floating solar PV system has been proposed for Loktak Lake, Manipur. The project was initiated by Manipur Renewable Energy Development Agency (MANIREDA) ${ }^{[24]}$. The Damodar Valley Corporation has also planned to setup 1000 MW worth solar system covering $2500 \mathrm{~km}$ of irrigation canal. Kerala is planning for another $1 \mathrm{MW}$ pilot project over Meenkara dam in Palakkad district. NHPC (National Hydroelectric Power Corporation) is also planning to set up a 50 MW floating solar PV project in Kerala ${ }^{[25]}$.

\subsection{Project Location}

Figure 1 shows the site map of green field development, whereas Figure 2 is a detailed map of the location with the proposed structural layout ${ }^{[26]}$. The hatched area shown in Figure 1 can be developed right from the scratch under the Greenfield development strategy, covering Sedarapet and Karasur village. The earmarked site is the southernmost lake present in the proposed smart city map, in the Karasur village of Pondicherry, India. The latitude and longitude of the location is: $11.98^{\circ} \mathrm{N}$ and $79.74^{\circ} \mathrm{E}$. At this particular location, we get a high amount of solar irradiation; thereby making it a very attractive site for the proposal of solar PV systems.

\section{Methodology and Materials}

The detailed literature search on the topic 'FSPV systems' was done using search engines such as web of knowledge, Scopus, and Google scholar. Free software 3D SketchUp 2015 modelling was used to prepare the geo-synchronized layout with Google map for the proposed water body. Basic survey accessories were used for manual survey of the site and compared with geo-synchronized layout. Solar irradiation, wind and temperature data were derived from NASA website.

\subsection{Methodology}

A manual survey on the proposed site was performed to determine the shadow casted by the structures present around the lake and orientation of the site. As the area comes under the Greenfield development policy,

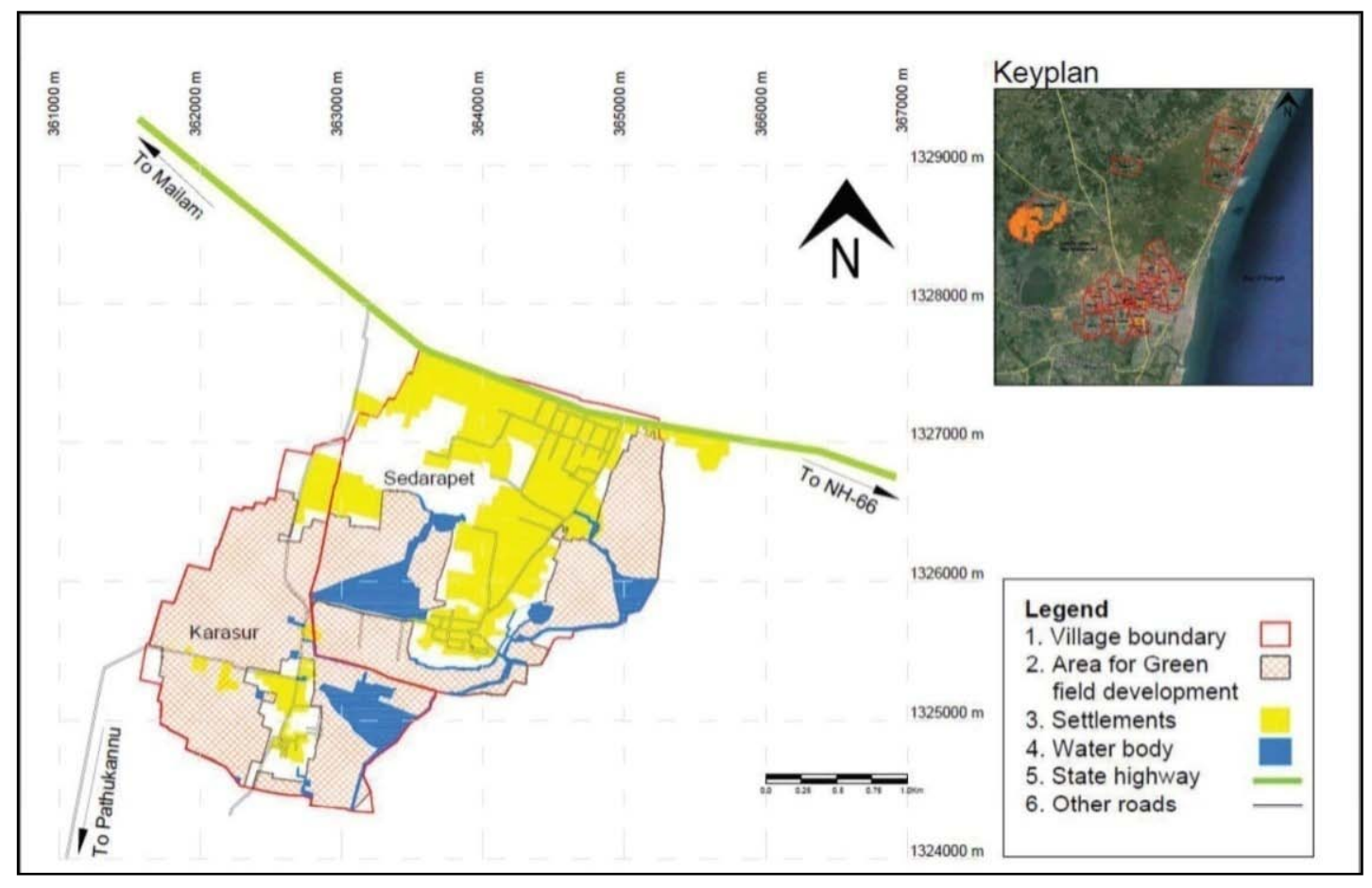

Figure 1. The site map for Greenfield development. 


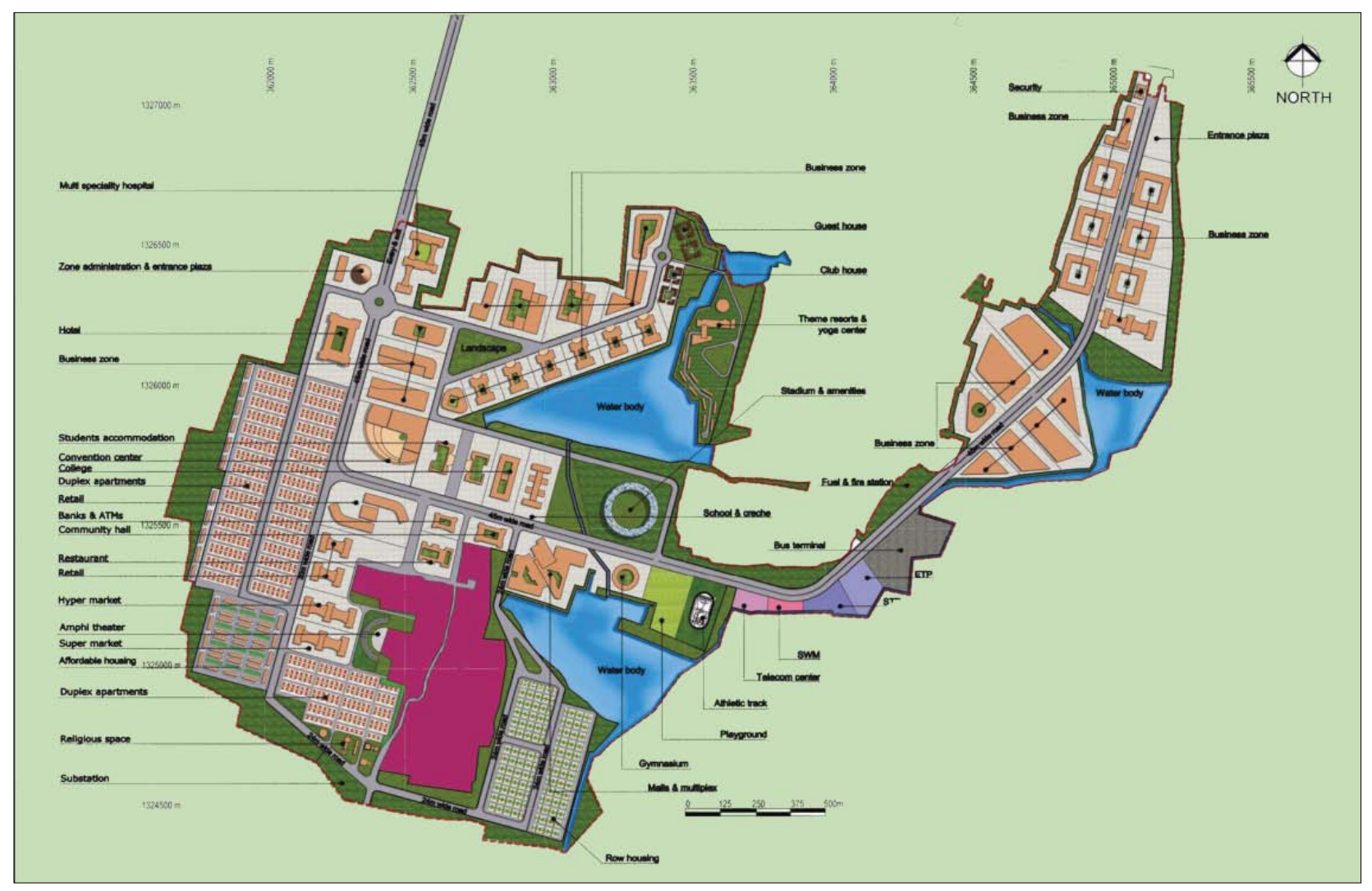

Figure 2. Site map with the proposed structural layout.

there is no construction work done around the location at present. With reference to the draft of the Oulgaret Smart city ${ }^{[26]}$ and the town planning authorities, there will be no shadow formed over the lake surface as the planned structure are on the south- western side of the lake and are not high enough to generate shadow on our proposed system. At present, the trees around the location which are 20-30 feet high cast shadow at the location but this can be eliminated at the time of installation for the smooth function of FSPV system.

Solar radiation data: The location receives a good amount of annual solar radiation with an average of $5.145 \mathrm{kWh} / \mathrm{m}^{2} /$ day. This amount of radiation is more than the average solar radiation and hence, it is an appropriate site for our system. Solar radiation data for the site has been derived from NASA website (http://eosweb.larc.nasa.gov/cgi-bin/sse). The monthly average solar radiation is shown in Figure 3.

Temperature data: The average monthly temperature of the site is $27.14^{\circ} \mathrm{C}$. The average monthly variation in ambient temperature profile for the site is shown in the Figure 4. As this temperature profile is measureed over land, there might be some variation when we consider the system over water body. This variation will always

\section{Days average daily solar radiation $(\mathrm{KWh} / \mathrm{m} 2 /$ day $)=\mathrm{PSH}$}

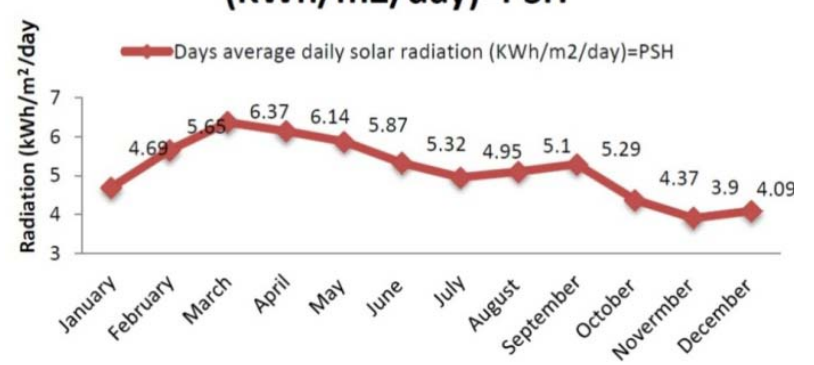

Figure 3. Monthly average solar radiation.

\section{Day time average temperature $(\operatorname{deg} \mathrm{c})$}

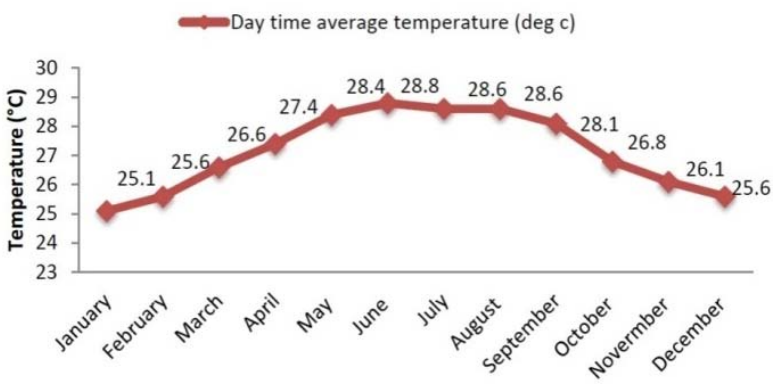

Figure 4. Monthly average temperature $\left({ }^{\circ} \mathrm{C}\right)$. 
be less than the temperature measured over land due to the evaporation of water and thus there will be no requirement of artificial cooling system.

Wind data: According to the data obtained for the wind velocities, the average annual wind velocity at the site is around $2.5 \mathrm{~m} / \mathrm{s}$. The monthly variation in the wind velocity is shown in Figure 5. The wind velocity is an important factor to be considered in our system as the wind might cause the change in the orientation of our system leading to decrease in the energy yield. As the site is close to the coast, conditions like storm and cyclone might prevail. For this, the system can be designed with appropriate materials such that it can withstand high wind velocities and reduce the damage imposed by the cyclonic winds.

\section{Average wind velocity $(\mathrm{m} / \mathrm{s})$}

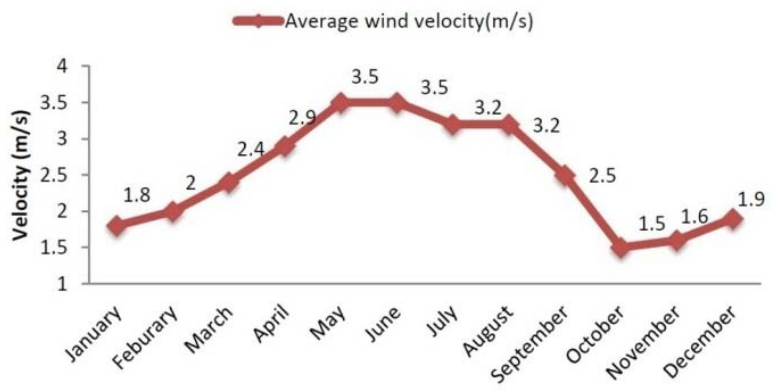

Figure 5. Monthly average wind velocity.

\subsection{Proposed Structural Materials}

\section{Floating Solar PV Systems}

Floating system: The first and foremost component required for our system is a floating structure which should be light weight, able to withstand the load of the setup and can be formed at a large scale. A site specific planning was done to determine the structure of floating system that can be designed to keep the setup afloat. We propose a hexagonal structure with each side of 60 $\mathrm{m}$ covering an area of $12471 \mathrm{~m}^{2}$. A total of three such hexagonal structures are proposed for the site which makes a total of $37412 \mathrm{~m}^{2}$. A pontoon type or a buoyant system has been suggested to achieve buoyancy and stability for this setup and arrangements should be made to accommodate the grids of panels designed (structural safety assessment of ocean-floating photovoltaic structure model) ${ }^{[27]}$. A light weight, high strength durable, fireproof material ${ }^{[28]}$ such as reinforced concrete shell with a core of expanded polystyrene (EPS) can be used. Pultruded fibre reinforced polymeric plastic (PFRP) is one such material which is superior to the conventional materials used for structural fabrication for a better result in floating $\mathrm{PV}^{[13]}$.

Mooring system: A mooring system is very important part of the system. The wind and other natural and man-made factors might cause a drift or change in the position of our system; this will result in decrease in our system efficiency due to change in orientation and might also result in physical damage to our system. To avoid these issues, an anchoring system using a high tensile strength material is to be devised so that it can fix the position of our system and also be useful to make adjustments during the variation in water level in the water body. The material preferred must have high Young's modulus, low density and high strength, such as polyester fibre.

Photovoltaic system: A photovoltaic system comprises of all the equipment that are required for the generation of electricity using the solar irradiation. In this section, we will discuss about the different equipment and their setup. For the proposal, we have considered a module with multi-crystalline technology. The modules generate $300 \mathrm{Wp}$ DC output, high torsion and corrosion resistance and high resistance to moisture ingress. Here, we have framed 4 panels together in a $2 \times 2$ arrangement for our purpose. The detailed specifications are as follows: maximum power $=300$ $\mathrm{Wp}$, open circuit voltage $\left(\mathrm{V}_{\mathrm{oc}}\right)=44.8 \mathrm{~V}$, short circuit current $\left(\mathrm{I}_{\mathrm{sc}}\right)=8.71 \mathrm{~A}$, module efficiency $(\eta)=15.10 \%$, dimensions $(\mathrm{L} \times \mathrm{W} \times \mathrm{H})=(1984 \times 1000 \times 40) \mathrm{mm}$. The technical drawing of the module is given in Figure 6.

Electrical system: The electrical system is considered as the soul of the system, it comprises of different devices and their connections which is vital for the functioning of a power plant. An inverter is regarded as the heart of the power plant; it is the device that regulates the voltage fluctuations and converts this fluctuating voltage into a single or three phase output which can be fed into the grids or stored into the storage devices. We have considered a water-proof micro-inverter as it optimizes each panel alone instead of doing it for the complete system as in case of a central inverter, which may be a weak link for the system and also causes decline in the output. The micro-inverters also reduce the need of a land based setup for the installation of a conventional central inverter. They also have a longer life than the conventional systems and in case of failure; it will not stall the production of the complete plant. The specifications of a grid tie microinverter are as follows: DC input with max. power input 310W, max. input DC voltage $=48 \mathrm{~V}$ and $\max$. 
DC short circuit current $=15 \mathrm{~A}$, MPPT efficiency $(\eta)=$ 99.4\%. The panel ratings lie within the range of the given three phase micro inverter rating. It produces an AC output which is synchronized to the grid frequency range and able to work under the atmospheric condition prevalent at the site of installation. The output of the three phase micro inverters is connected in parallel. This output can be further enhanced using a three phase step-up transformer $440 \mathrm{~V} / 11 \mathrm{kV}$ depending upon the requirement of the utility grid.

Other electrical accessories: The cables must con-

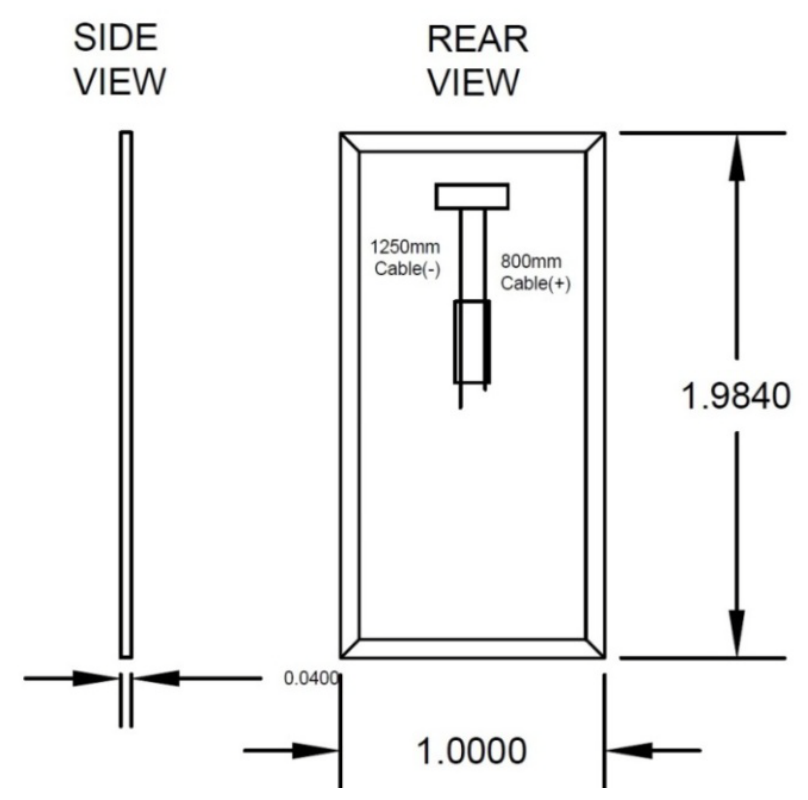

Figure 6. Technical drawing of the module.

\section{Project Implementation Array Spacing and Layout}

The proposed site for our floating solar PV power plant is the southernmost water body in the proposed smart city map. According to the town planning officials, the proposed map shows low rise settlements on the south-western side of the site and it might merely cast a noon shadow on our system. A set of four modules were framed together in $2 \times 2$ configurations with a total of 4 panels together in a portrait layout. This frame gives a clearance of $0.152 \mathrm{~m}$ to the module from the ground. The modules are tilted at an angle of $12^{\circ}$ from the base. Figure 8 shows the layout of individual module. This was performed by using 3D modelling software SketchUp Pro 2015 along with the array-o-matic_v1.11 component plugin to $0.95 \mathrm{~m}$ between the modules in the same row and $2.83 \mathrm{~m}$ spac- form to the marine grade and need to be selected accordingly to keep the voltage drop and losses to minimum. Interconnections, combiner boxes, junction boxes etc. should be selected properly according to the regional standard. All the accessories have to work under the prevalent atmospheric condition and electrical rating. A net-metering device needs to be installed to keep a check on the inflow and outflow of the power to and from the grid. It provides an insight of the generation. The electrical layout of the floating SPV system is shown in Figure 7.

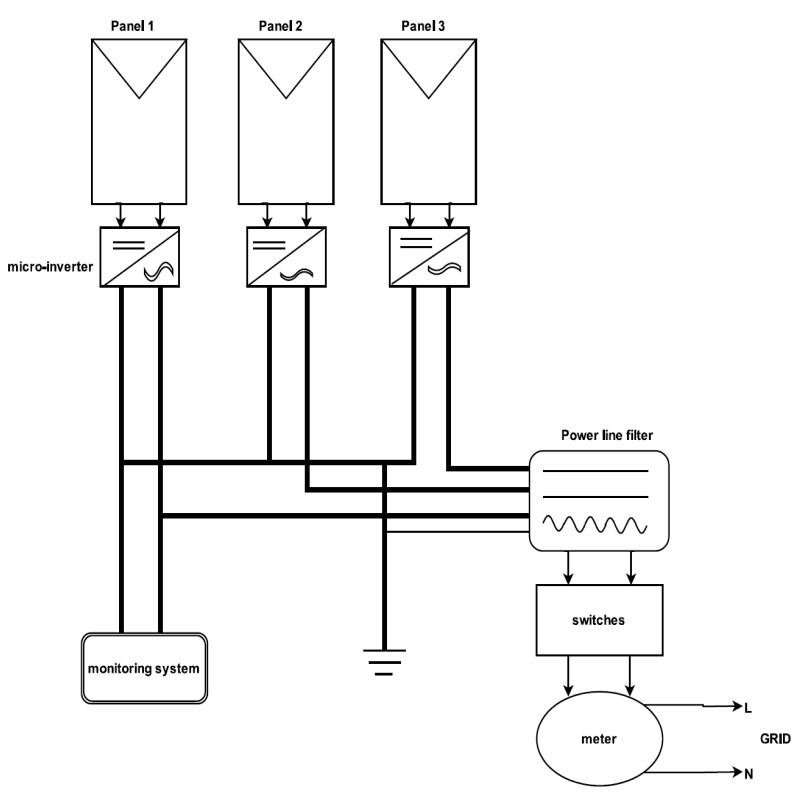

Figure 7. Electrical layout of floating SPV system.

ing between adjacent rows. This spacing also includes the gap for maintenance and cleaning purposes.

The active area, i.e., the total area estimated in electricity generation by incident solar irradiation, is $13416 \mathrm{~m}^{2}$ out of $37412 \mathrm{~m}^{2}$. An area of $2065 \mathrm{~m}^{2}$ was provided on the right end of the floating structure to accommodate the junction boxes and other electrical devices. Figure 9 to Figure 11 shows the proposed layout of the plant, front view and side view of the floating SPV power plant.

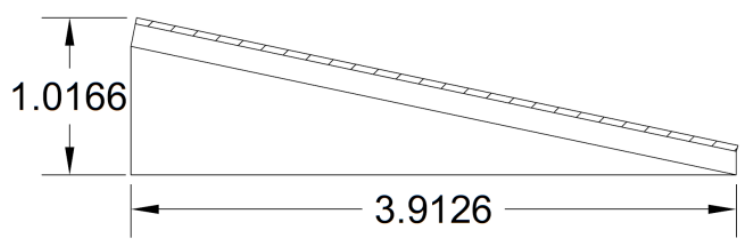

Figure 8. Layout of individual module. 


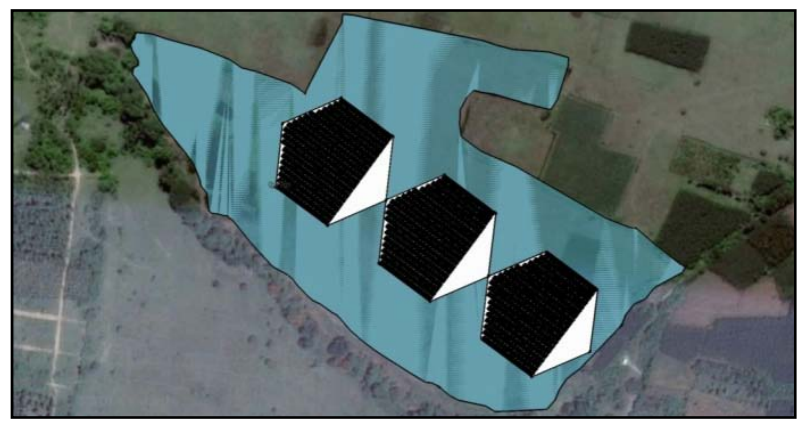

Figure 9. Layout of the floating SPV power plant.

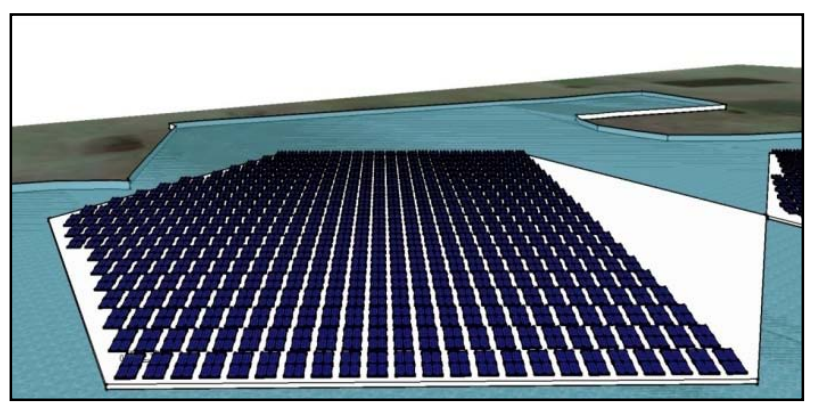

Figure 10. Front view of the floating SPV power plant.

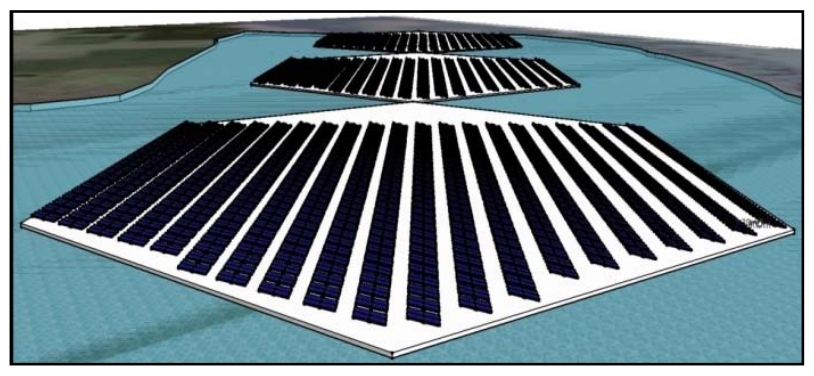

Figure 11. Side view of the floating SPV power plant.

\section{Estimation for Annual Yield}

To obtain the annual energy yield, various standard parameters such as daytime temperature, NOCT, annual degradation, etc., are considered. A total of 6708 panels of $300 \mathrm{Wp}$ each are considered for our system, making it a 2MW system. By utilizing the parameters, losses and other factors we estimate the total annual yield of 2946.5 MWh for the first year and 2433.5 MWh for the $25^{\text {th }}$ year. The average energy yield of the plant taking the life time to be 25 years is $2658 \mathrm{MWh}$ annually. This yield will be about $7.5 \%$ greater than the land based system.

\section{E-Transport Facility and Its Trend}

The electric vehicles or EV's can be classified depending upon the technology being used to provide energy to the electrical drive. Mainly two technologies are being focused on, namely fuel cell and battery. Battery technology is being used for the analysis in this report as it is being widely used at a commercial lev$\mathrm{el}^{[29]}$. Emphasis on a major concern that EV integration will put burden on grid and thus, many studies have been conducted to mitigate the impacts of EV onto grid ${ }^{[30]}$. The researchers believed that there will be more pollution if energy from non-renewable sources of energy is fed into the grid; thus, it is better to have more share of renewable energy power plants integrated with the grid $^{[31]}$. The present difficulties with EV technology is battery cost and range anxiety that it gives while in use; thus causing a concern on reliability and it cannot be ignored that even if EV range exceeds or is equal to gasoline vehicle, it will add to increase the weight and size of the vehicle, thus making the vehicle less efficient and more expensive ${ }^{[32]}$.

The EV industry is going to pick up growth only if major areas like government policy and regulation, technology, customer power are worked on by the private sector in tandem with the public sector ${ }^{[33]}$. The study highlighted the points that governments around the world are providing subsidy on EV's is acting as a boon to the industry; this trend should continue and more tax incentives should be provided to EV manufacturers and $\mathrm{EV}$ owner ${ }^{[34]}$. The integration of renewable energy into the residential grids will pave way for electric vehicles ${ }^{[35]}$. A comparison between the economic status, showing that $80 \%$ of the e-rickshaw drivers have felt an increase in their daily wages and betterment in their living condition after shifting into this profession from their previous ones ${ }^{[7]}$. According to the press release by the ministry of road transport and highways in June 2014, the union minister has proposed a scheme to the prime minister that might be called 'Deendayal E-Rickshaw Scheme' to empower the use of e-rickshaws and also using it as a means to overcome the poverty ${ }^{[9]}$.

\subsection{E-Rickshaw Specification}

The e-rickshaw is a battery powered vehicle that can be used for commuting for short distances of 5-10 Kms. The e-rickshaws being proposed in our project has the following specifications:

(i) It is powered by a $800 \mathrm{~W}$ brushless DC motor which is supported by $90 \mathrm{Ah} / 48 \mathrm{~V}$ battery bank incorporating lead-acid technology.

(ii) The batteries used are deep discharge batteries with $80 \%$ depth of discharge (DOD). Their complete 
charging of the battery will require almost $8.817 \mathrm{kWh}$.

(iii) It has a frame/chassis of steel with a differential transmission mode.

(iv) It has rear wheel drive and can carry up to 6 passengers at a time.

(v) It covers a distance of $70 \mathrm{Kms}$ in one complete charge.

\subsection{Charging Facility Specification}

The charging facility is proposed to be established at parking facility in the vicinity of the proposed floating solar PV power plant. This is to extend the benefits of the solar PV plant to support the purpose of efficient urban mobility and public transport. The charging facility will have 15 Amps DC charging facility with 48V output. We propose to install 20 such points at the parking facility to support 20 e-rickshaws as a pilot initiative. Similar facilities can be replicated at different part of the city where the route is most suitable and on which these vehicles could be used to maximize the commercial benefit. Energy storage capacity of the battery bank is estimated as $8817 \mathrm{Wh}$, i.e., $8.817 \mathrm{kWh}$. Hence, we require a total of $176.3 \mathrm{kWh}$ of energy charge 20 e-rickshaws per day. The $2 \mathrm{MW}$ plant can be expected to generate $8000 \mathrm{kWh}$ of energy per day. The energy extracted from the grid will be $176.3 \mathrm{kWh}$ of energy per day for the charging station. This will amount to $2.20 \%$ of energy produced by the solar PV plant every day. The charging time could vary from $6-7$ hours to completely charge each rickshaw as we have plans to charge the battery at $\mathrm{C} / 6$ rate.

\section{Cost Estimation and Payback Period}

As per literature review, the cost of the floating system is about 1.2 times greater than the conventional land based system ${ }^{[5]}$ but in this cost, the land cost is not considered which is required for a land based system. The cost of the floating solar PV system can be estimated around USD 1.6 million. The payback period is the time span in which the cost of the yield becomes equal to the capital invested in installation. According to the current solar tariff of USD 0.10 per $\mathrm{kWh}$ for floating system, the payback period is expected to be less than 6 years without the subsidy provided by different state and national funding agencies. As per the market research, the total capital expenditure for the e-rickshaw and its charging facility is estimated to be USD 30,000. Considering that the maximum operating days to be 300 , the cost of electricity taken from the grid will be around USD 5500 per annum at USD 0.10 per kWh electricity rate (in Pondicherry, India). Electricity cost per e-rickshaw per day will be close to USD 1. The maintenance cost will be around USD 75 per annum. This will make the operational expenditure per vehicle per day to be around USD 1.2. According to the market data available, the earnings per day from the single vehicle will be around USD 11 . Therefore, the profit earned from 20 e-rickshaws will be around USD 196. The payback period for the system will be just 5 months approximately.

\section{Conclusion}

The proposal for a 2MW floating solar photovoltaic power plant can be implemented in different phases as it requires a decent capital cost including the maintenance cost. The challenges to be dealt are the fabrication of huge floating structure, protection during cyclones and other such natural calamities, high grade waterproof cabling, high tensile strength and corrosion resistance anchoring cables, water ingress resistant modules and other electrical devices. The high average solar irradiation of $5.145 \mathrm{kWh} / \mathrm{m}^{2} /$ day received in the proposed location makes it a perfect location for installation of solar photovoltaic technology. We performed shadow analysis by using 3D modelling software SketchUp Pro 2015 along with the array-o-matic_v1.11 component plug in to be $0.95 \mathrm{~m}$ between the modules in the same row and $2.83 \mathrm{~m}$ between the adjacent rows. The FSPV system consists of three hexagonal structures of $12470 \mathrm{~m}^{2}$ each with the active area of $4472 \mathrm{~m}^{2}$ accommodating 559 modules of 4 panels each, making the system to be a total area of $37412 \mathrm{~m}^{2}$, with the total active area to be $13416 \mathrm{~m}^{2}$ consisting a total of 1677 modules of 6708 panels of $300 \mathrm{~kW}$ each. The high average annual energy yield of $2658 \mathrm{MWh}$ will make it better with around $~ 7.5 \%$ higher efficiency than the land based system. Three phase grid tied micro-inverters has been proposed. The output will be stepped up further using a step up transformer of $440 \mathrm{~V} / 11 \mathrm{kV}$ or others as per the utility grid requirement. It has been calculated that the payback period will of less than 6 years without the subsidy provided by the related agencies. Once commissioned fully, it can save 6000 tonnes of $\mathrm{CO}_{2}$ during its life span of 25 years. The proposed e-rickshaw and its charging facility required a capital cost of USD 30,000 and the operational cost to be around USD 1.2 per e-rickshaw per day. The profit earned per day on the capital expenditure will be 
USD 196 and the payback period will be around 5 months. The fleet of e-rickshaw will replace a fleet of diesel run vehicle, thereby offsetting 56.3 tonnes of $\mathrm{CO}_{2}$ per year from direct exposure on roads. This together will make our proposal of USD 1.6 million and the payback period of less than 5 years with reduction of 7400 tonnes of $\mathrm{CO}_{2}$ emission in the atmosphere.

\section{Conflict of Interest and Funding}

No conflict of interest was reported by all authors. One of the authors (A.K.S) acknowledges MNRE (Ministry of New and Renewable Energy, India) for providing the scholarship to support his studies at Centre for Green Energy Technology, Pondicherry University.

\section{References}

1. United Nations, Department of Economic and Social Affairs, Population Division, 2014, World urbanization prospects, viewed September 10, 2016, $<$ https://esa.un.org/unpd/wup/Publications/Files/WUP2 014-Highlights.pdf>

2. Strategy, viewed January 30, 2015, $<$ http://www.smartcities.gov.in/writereaddata/Strategy.p $\mathrm{df}>$

3. Ministry of Urban Development Government of India, 2015, India smart city mission, viewed September 3, 2016, <http://smartcities.gov.in/writereaddata/winningcity/Da vanagereSCP.pdf>

4. Cseindia.org, 2015, GEF national workshop in India (MNRE), May 13, 2015: Renewable energy in India: Growth and targets, viewed August 30, 2016, <http://cseindia.org/docs/photogallery/ifs/Renewable Energy in India Growth and Targets.pdf>

5. Swapnil D, Jatin N S, and Bharath S, 2013, Temperature dependent photovoltaic (PV) efficiency and its effect on PV production in the world - A review. Energy Procedia, vol.33: 311-321. https://doi.org/10.1016/j.egypro.2013.05.072

6. Subhash C, Purohit A, Anshu S, et al., 2015, A study on photovoltaic parameters of mono-crystalline silicon solarcell with cell temperature. Energy Reports, vol.1: 104-109. http://dx.doi.org/10.1016/j.egyr.2015.03.004

7. Paritosh S, Bharat M, and Debojyoti S, 2015, Design parameters of $10 \mathrm{kw}$ floating solar power plant. International Advanced Research Journal in Science, Engineering and Technology, vol.2: 85-89. http://dx.doi.org/10.17148/IARJSET

8. Ministry of Urban Development, Government of India, 2016, Smart city mission, viewed September 16, 2016, $<$ http://smartcities.gov.in/writereaddata/Ranking_of_Sm art\%20Cities.pdf>
9. Press Information Bureau, Ministry of Road Transport and Highways, Government of India, 2014, Proposed Deendayal e-rikshaws scheme, viewed July 30, 2016, $<$ http://pib.nic.in/newsite/PrintRelease.aspx?relid=105700>

10. Shashank S, 2014, A study of the battery operated e-rickshaws in the state of Delhi: Researching Reality Summer Internship Report, Centrefor Civil Society, $<$ https://ccsinternship.files.wordpress.com/2014/06/323 _study-of-the-battery-operated-erickshaws-in-the-stateof-delhi_shashank-singh.pdf>

11. Choi Y-K, 2014, A case study on suitable area and resource for development of floating photovoltaic system. International Journal of Electrical, Computer, Energetic, Electronic and Communication Engineering, vol.8: 828-832.

$<$ http://scholar.waset.org/1999.5/9999567>

12. Choi Y-K, 2014, A study on power generation analysis of floating PV system considering environmental impact. International Journal of Software Engineering and Its Applications, vol.8: 75-84. https://doi.org/10.14257/ijseia.2014.8.1.07

13. Lee Y-G, Joo H-J, and Yoon S-J, 2014, Design and installation of floating type photovoltaic energy generation system using FRP members. Solar Energy, vol.108: 13-27.

https://doi.org/10.1016/j.solener.2014.06.033

14. Choi Y-K, Lee N-H and Kim K-J, 2013, Proceedings, The 3rd International conference on circuits, control, communication, electricity, electronics, energy, system, signal and simulation: Empirical research on the efficiency of floating $P V$ systems compared with overland PV systems. vol.25: 284-289.

$<$ http://onlinepresent.org/proceedings/vol25_2013/66.pdf>

15. Ferrer-Gisbert C, Ferrán-Gozálvez J J, Redón-Santafé M, et al., 2013, A new photovoltaic floating cover system for water reservoirs. Renewable Energy, vol.60: 63-70. http://dx.doi.org/10.1016/j.renene.2013.04.007

16. Polienergie s.r.l, 2012, Floating photovoltaic system, viewed September 15, 2016,

$<$ http://polienergie.com/img/floating_photovoltaic_syst em_ENG.pdf>

17. Trapani K, Millar D L, and Smith H C M, 2013, Novel offshore application of photovoltaics in comparison to conventional marine renewable energy technologies. Renewable Energy, vol.50: 879-888. http://dx.doi.org/10.1016/j.renene.2012.08.043

18. Trapani K and Millar D L, 2013, Proposing offshore photovoltaic (PV) technology to the energy mix of the Maltese islands. Energy Conversion and Management, vol.67: 18-26.

https://doi.org/10.1016/j.enconman.2012.10.022

19. Fiaschi D, Manfrida G, Secchi R, et al., 2012, A versatile system for offshore energy conversion including diversified storage. Energy, vol.48: 566-576.

https://doi.org/10.1016/j.energy.2012.10.006

20. Ho C J, Chou W, Lai C, 2014, Thermal and electrical 
performance of a water-surface floating PV integrated with a water-saturated MEPCM layer. Energy Conversion and Management, vol.89: 862-872.

https://doi.org/10.1016/j.enconman.2014.10.039

21. Redón Santafé M, Soler J B T, Romero F J S, et al., 2014, Theoretical and experimental analysis of a floating photovoltaic cover for water irrigation reservoirs. Energy, vol.67: 246-255.

http://dx.doi.org/10.1016/j.energy.2014.01.083

22. Redón Santafé M, Ferrer Gisbert P S, Romero F J S, et al., 2014, Implementation of a photovoltaic floating cover for irrigation reservoirs. Journal of Cleaner Production, vol.66: 568-570. https://doi.org/10.1016/j.jclepro.2013.11.006

23. Sacramento E M do, Carvalho P C M, Araújo J C de, et al., 2015, Scenarios for use of floating photovoltaic plants in Brazilian reservoirs. IET Renewable Power Generation, vol.9: 1019-1024.

https://doi.org/10.1049/iet-rpg.2015.0120

24. Chakraborti S, 2015, Country's biggest floating solar plant to come up at Manipur's Loktak Lake, viewed September 7, 2016,

$<$ http://timesofindia.indiatimes.com/city/kolkata/Countr ys-biggest-floating-solar-plant-to-come-up-at-Manipurs -Loktak-Lake/articleshow/47576349.cms>

25. D'Monte D, 2015, Maharashtra races to build India's first solar farm on dam wall, viewed September 8, 2016, $<$ http://www.huffingtonpost.com/entry/maharashtra-rac es-to-buil_b_6343148.html?section=india>

26. Government of India, Ministry of Urban Development, n.d., Draft Smart City Proposal - Oulgaret, viewed September 8, 2016,

$<$ http://www.smartcitieschallenge.in/files/dmfile/DraftSmart-Cities-Proposal-oulgaret1.pdf>

27. Choi Y-K and Lee J-H, 2015, Structural safety assessment of ocean-floating photovoltaic structure model. Israel Journal of Chemistry, vol.55: 1081-1090. https://doi.org/10.1002/ijch.201400197
28. Koekoek M J, 2010, Connecting modular floating structures: a general survey and structural design of a modular floating pavilion, Master thesis, TU Delft University, viewed July 30, 2016,

$<$ http://repository.tudelft.nl/islandora/object/uuid:33b59 201-1718-4dda-98f8-ee16d5b7c023?collection=educati on>

29. Wu H and Chang S, 2013, Exploration of a mobile service business model for electric vehicle charging stations. Journal of Industrial and Production Engineering, vol.30: 363-371.

http://dx.doi.org/10.1080/21681015.2013.849765

30. Richardson D B, 2013, Electric vehicles and the electric grid : a review of modeling approaches, impacts, and renewable energy integration. Renewable and Sustaiable Energy Reviews, vol.19: 247-254.

https://doi.org/10.1016/j.rser.2012.11.042

31. Tie S F and Wei C W, 2013, A review of energy sources and energy management system in electric vehicles. Renewable and Sustainable Energy Reviews, vol.20: 82-102. https://doi.org/10.1016/j.rser.2012.11.077

32. Colella W G, 2000, Market prospects, design features, and performance of a fuel cell-powered scooter. Journal of Power Sources, vol.86: 255-260. https://doi.org/10.1016/S0378-7753(99)00486-3

33. Becker D and Nagporewalla Y, 2010, The Indian automotive industry: evolving dynamics, KPMG International, viewed August 4, 2016, <https://www.kpmg.de/docs/Auto_survey.pdf>

34. Yap W K and Karri V, 2008, Modeling and simulation of a hybrid scooter. International Journal of Electrical and Electronics Engineering, vol.2: 693-698. https://doi.org/10.1504/IJEHV.2009.027676

35. Pillai J R, Huang S, and Bak-Jensen B, 2013, Conference on Power and Energy Society General Meeting (PES) 2013 IEEE, July 21-25, 2013: Integration of solar photovoltaics and electric vehicles in residential grids. http://dx.doi.org/10.1109/PESMG.2013.6672215 